\title{
Recent dynamics (1995-1999) of the phytoplankton assemblages in Lago Maggiore as a basic tool for defining association patterns in the Italian deep lakes
}

\author{
Giuseppe MORABITO*, Delio RUGGIU and Pierisa PANZANI \\ CNR - Istituto per lo Studio degli Ecosistemi, Largo Tonolli 50, 28922 Pallanza, Italy \\ *e-mail corresponding author: g.morabito@iii.to.cnr.it
}

\begin{abstract}
The main goal of the study presented here is to identify a repeatable pattern in the seasonal succession of phytoplankton assemblages in Lago Maggiore. In order to fulfil this objective we analysed the phytoplaktonic succession during a five years period (1995-1999), through the calculation of the Bray-Curtis similarity index applied to biovolume data. A cluster analysis has been then applied to the distance matrix, allowing the identification of sample clusters possessing a similar species composition. The comparison, through the whole period considered, of the phytoplankton assemblages characterising each cluster allowed to recognise six seasonal periods (Winter, Early Spring, Late Spring, Early Summer, Late Summer, Autumn), each of them characterised by a peculiar and repeatable species assemblage. Among the most interesting findings we would mention the existence of a Late Spring/Early Summer association, dominated by Planktothrix rubescens and Fragilaria crotonensis, probably peculiar of the deep subalpine lakes, where these species can better take advantage of the physical and chemical environment of the metalimnetic niche. The identification of a pool of dominant and sub-dominant species common to other southern subalpine lakes and the existence of a similar time periodicity in the development and decline of most of them across this lake district seem to be promising in order to give our results a wider application.
\end{abstract}

Key words: phytoplankton assemblages, association pattern, deep subalpine lakes

\section{INTRODUCTION}

About two decades ago Harris (1980) stated that to predict the outcome of a phytoplankton succession in terms of species composition is almost impossible. More recently, Reynolds (1998) recognised that the basic question facing the phytoplanktologists is, once again, the following: "what lives where and why?"

A great stimulus to investigate where and when particular phytoplankton species might dominate came from studies of eutrophication and lake management, in the attempt to predict and, possibly, avoid blooms of undesirable species. The major effort was paid in trying to understand the role of algal nutrients, phosphorus in particular, as factors controlling the phytoplankton growth. In the most recent years Reynolds (1997, 1998, 1999) emphasised that more than a single environmental variable (such as nutrients) is at play when species are actively selected: basin morphometry, light quality and intensity, mixing dynamics (these last three related with local climatic constraints), water clarity, grazing pressure, alkalinity are frequently mutually co-varying, identifying the boundaries of the habitat template of each phytoplankter.

The development and, eventually, dominance of particular species is not completely random, but, as Reynolds (1999) stated, "biased probabilistically towards species whose physiological attributes are better suited than most of the others" to a particular set of habitat conditions. However, even with a precise knowledge of the range of environmental variables favourable for the growth of a certain organism, it is difficult to make reliable predictions about the details of a phytoplankton succession: this is particularly true in large lakes, which can maintain a large pool of species (Padisák 1992) and, due to the large habitat diversity, provide refuges where species can survive unfavourable periods and from where they may re-colonise the pelagic environment when the conditions are less hostile (Padisák \& Dokulil 1994). On the other side, large and deep lakes usually show a more or less high resistance to a disturbance, either on a short or long time scale. This kind of system can thus maintain for a long time a stable habitat, which represents a basic condition for a certain phytoplankton assemblage to establish itself as the dominant one. Because of this smoothed variability, the phytoplankton succession can be more similar from year to year in deep lakes than in shallow lakes. This seemed to be the case for the southern subalpine deep lakes: in spite of their different trophic state, Ruggiu (1983), after comparing the phytoplankton assemblages found in lakes Maggiore, Lugano, Como, Iseo and Garda, concluded that phytoplankton composition seemed to be largely dependent on similar geographic, morphometric and hydrodynamic features, whereas the biomass level was mainly determined by the nutrient load. 


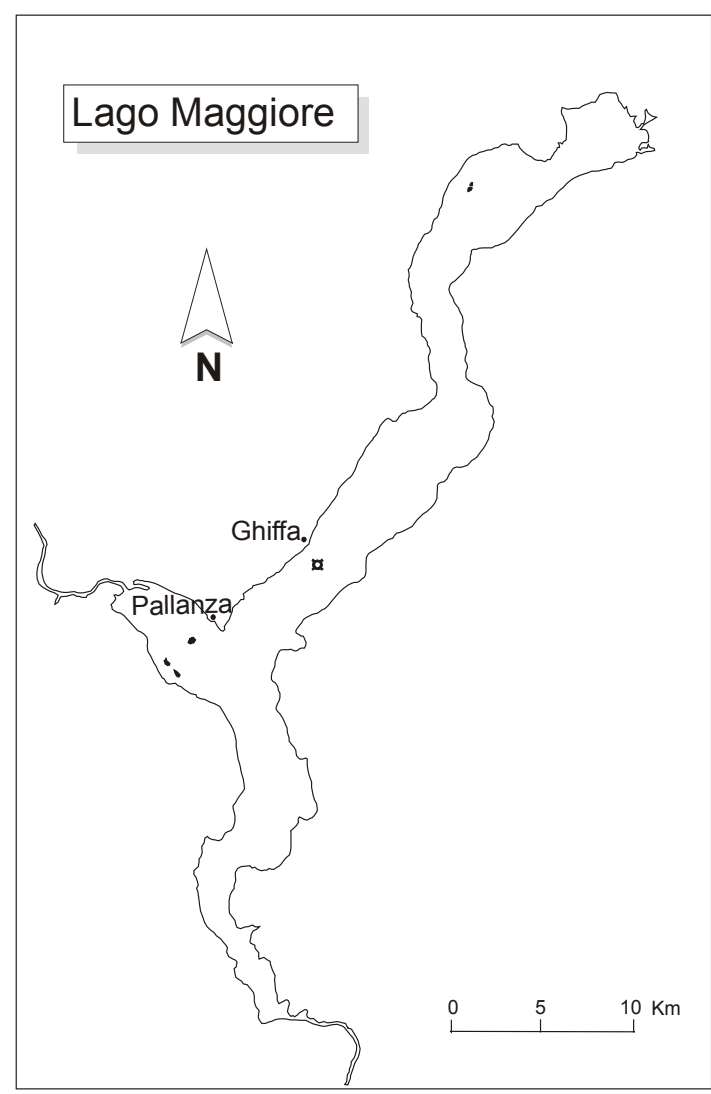

Fig. 1. Map of Lago Maggiore. The sampling station is indicated by an asterisk.

Together with a large set of papers on the phytoplankton of these lakes, these findings represent a starting point towards the possibility to identify phytoplankton associations common to the deep southern subalpine lakes, and stimulated the study carried out by the phytoplankton working group set up in 1999 in the frame of an Italian - Swiss research project on the ecological quality and management of the deep lakes (acronym GLAP).

Tab. 1. Main morphometric and hydrological features of Lago Maggiore.

\begin{tabular}{lc}
\hline Altitude $(\mathrm{m}$ a.s.l.): & 194 \\
Drainage basin area $\left(\mathrm{km}^{2}\right):$ & 6599 \\
Volume $\left(\mathrm{m}^{3} \times 10^{6}\right):$ & 37,500 \\
Area $\left(\mathrm{km}^{2}\right):$ & 212 \\
Max depth $(\mathrm{m}):$ & 370 \\
Mean depth $(\mathrm{m}):$ & 177.5 \\
Turn over time (yrs): & 4.1 \\
\hline
\end{tabular}

In this paper we present the phytoplankton assemblages recognised in the course of the seasonal succession, during five years, in Lago Maggiore: starting from the identification of typical seasonal assemblages, the main goal of this paper is to provide a basic information for the characterisation of phytoplankton associations typifying the deep subalpine lakes. We analysed the as- sociation patterns observed in Lago Maggiore taking into account, whenever possible, the role of the many variables (physical, chemical and biotic) involved in the regulation of a phytoplankton succession and considering also the functional properties embedded into the morphology of the algal cells and coenobia (see Reynolds 1997).

\section{STUDY SITE AND EARLIER WORK}

Lago Maggiore, the second largest Italian subalpine lake (Fig. 1; Tab. 1), is oligotrophic by nature, as testified by early limnological studies (Monti 1929; Baldi 1949; Vollenweider 1965) and by the analysis of the sedimentary pigments (Guilizzoni et al. 1983; Marchetto et al. 2000). The eutrophication process started in the sixties: the algal nutrient concentration in the lake water started to increase and was soon followed by an increase of the phytoplankton abundance, biovolume and primary productivity (Ruggiu \& Saraceni 1977; Ravera \& Vollenweider 1968; Morabito \& Pugnetti 2000). The lake reached a trophic state close to eutrophy in the late seventies, when the P loads peaked and the maximum in-lake TP concentration at winter mixing was recorded (around $30 \mu \mathrm{g} \mathrm{l}^{-1}$; Mosello \& Ruggiu 1985). Since that time, the $P$ loads have been gradually reduced by various means, among which the adoption of treatment plants and the reduction of total phosphorus in detergents were the most important. As a result, the values of TP at winter mixing gradually decreased to values around $10 \mu \mathrm{g} \mathrm{l}^{-1}$ in the most recent years (Calderoni et al. 1997). The slow reversal of the trophic state of Lago Maggiore is documented by many papers: from a biological point of view, strong emphasis was put in the eighties on the apparent resilience of the plankton communities against falling phosphorus (de Bernardi et al. 1988). However, starting from 1987-88, major biological changes were at last manifest, especially in the phytoplankton (Manca et al. 1992; Ruggiu 1993). Notable changes were also recorded in the structure of the phytoplankton assemblages with oligotrophication (Ruggiu et al. 1998): among the most important of these, we must mention a remarkable decrease of the average cell size due to an increased importance of the smaller sized phytoplankters, a pattern which could involve deep changes in the whole ecosystem functioning (Harris 1994).

\section{METHODS AND DATA TREATMENT}

Water samples for phytoplankton analysis were collected fortnightly, or often monthly during January, February, November and December, at the station of Ghiffa, corresponding to the deepest point of the lake. A bottle designed to take an integrated sample in the 0-20 $\mathrm{m}$ water layer was used. Phytoplankton determinations were carried out on subsamples preserved in acetic Lugol's solution; algal cells (including ultraplankton cells 
of about 3-4 $\mu \mathrm{m}$ diameter) were counted on a Zeiss Axiovert 10 microscope, following Lund et al. (1958), until 400 cells for the most important species were counted. Phytoplankton biomass was estimated from density data and original measurements of cell volume (Smayda 1978). Species were identified using the series Süßwasserflora von Mitteleuropa and Das Phytoplankton des Süßwassers. Oscillatoriales were determined following also Anagnostidis \& Komárek (1988).

Water for chemical analysis was collected monthly and the chemical parameters have been determined at the chemical laboratory of the Istituto per lo Studio degli Ecosistemi (Pallanza), following the methods reported in Mosello \& Ruggiu (1985).

Underwater PAR attenuation was measured using a LiCor Li-250 radiometer equipped with a LiCor Li-192 SB underwater quantum sensor; temperature profiles were obtained by means of a thermistor probe.

The meteorological data considered in the following paragraph are total monthly values, derived from measurements made at the Institute meteorological station in Pallanza.

We calculated the dissimilarity between pairs of samples using the Bray and Curtis index computed on biovolumes of identifiable algae, after a square-root transformation of the raw data, as suggested by Salmaso (1996). The computation of the Bray and Curtis index was carried out with SIMDISS 2.0 (http://www.bio.unipd.it/limno/simdiss/), whereas the cluster analysis was performed with Statistica package by StatSoft Inc. (1997).

After calculating the distance matrix on the whole data set (1995-1999), in order to simplify the interpretation of the results, we decided to calculate a distance matrix for each yearly data set. Then, by calculating the mean density of each sample cluster, a second data set in which every year was represented by seasonal groups was obtained. In this way we reduced the whole data set to a smaller matrix, making it easier to compare the seasonal communities from year to year. The identified seasonal groups were named as follows: $\mathrm{W}=$ Winter (from January to half March), ESP = Early Spring (half March-half May), LSP = Late Spring (half May-June), $\mathrm{ESU}=$ Early Summer (July), LSU = Late Summer (August-September), A = Autumn (October-December).

In the assemblages analysis, carried out after the identification of the seasonal clusters (Tab. 2), we included those species which, at least once during the seasonal cycle, contributed to build up $80 \%$ of the total community biovolume. According to their relative biovolumes, we divided the selected species in each seasonal association into three categories: dominant (more than $10 \%$ of total biovolume), sub-dominant (between 5 and $10 \%$ of total biovolume) and important (species remaining to reach the $80 \%$ threshold). We identified the phytoplankton associations corresponding to the main sequence of the seasonal succession (Tab. 3) extracting from the yearly seasonal clusters those species characterising a seasonal assemblage at least in three years of the five studied. In this way, we defined seasonal assemblages which we consider typical of Lago Maggiore, at least for the five years considered.

\section{PHYSICAL ENVIRONMENT}

\subsection{Solar radiation, rainfall and surface water temperature}

The local climatic conditions showed a remarkable variability during the study period: because the climatic constraints have been often indicated as important factors in controlling the phytoplankton dynamics in Lago Maggiore (see Morabito, 2001 and references therein), we report in this chapter a short description of the trends followed by the three main meteorological parameters in the period 1995-1999. The monthly average values of the total incident solar radiation recorded at the meteorological station in Pallanza showed very high values during March, April and May 1997, followed by a strong decrease in June and a new period of high solar radiation from July to November. On the other side, the year 1996 was characterised by a lower amount of radiation during the winter months and during July and August. In 1995 the annual peak was recorded in July, whereas in August and particularly in September this parameter fell to very low values. Winter 1998 showed quite high values until March, but in April a strong decrease was observed. During summer and late summer the monthly averages were the highest of the whole study period. Spring 1999 showed average values similar to those recorded in 1996, but the yearly peak was reached in July, as in the remaining years (except 1996). In August a sharp decrease of the solar radiation was observed; however, from September to December values comparable to those of 1998 were recorded.

As concerns the rainfall amount, a certain year-toyear variability has been recorded: in general, the winter period is characterised by low rainfall, spring and/or autumn can be the most rainy seasons, but peaks can occur also in different months. In 1995 two peaks of rainfall were recorded, the first in April and the second in September; 1996 showed three peaks (January, May and November), but also high values during July and August, followed by a September with very scarce rain. After the peak recorded in November 1996, the rainfall amount was very low until April 1997: in June 1997 the yearly maximum took place, followed by a summer period characterised by scarcity of precipitation and a second peak in November. The rain was scarce again during winter 1997-1998, then a peak was observed in the next April, while in the rest of spring and summer rainfall was low again until September (second yearly peak). High precipitation was also recorded during December 1998. 
Tab. 2. Phytoplankton assemblages at different seasonal periods. Dominant (BV $>10 \%$, bold type), sub - dominant $(5 \%<\mathrm{BV}<10 \%$, underlined) and important (BV $<5 \%)$ species are reported. Abbreviations of species as follows: Pla. rub., Planktothrix rubescens; Osc. lim., Oscillatoria limnetica; Aul.isl.hel., Aulacoseira islandica morf. helvetica; Lim. sp., Limnothrix sp.; Mal. cau., Mallomonas caudata; Aul. amb., Aulacoseira ambigua; Cer. hir., Ceratium hirundinella; Rho. min., Rhodomonas minuta; Rho. lac., Rhodomonas lacustris; Rhi. eri., Rhizosolenia eriensis var. morsa; Dia. ten., Diatoma tenuis; Fra. cro., Fragilaria crotonensis; Mou. sp., Mougeotia sp.; Aph. cla., Aphanothece clathrata; Cyc. com., Cyclotella comensis; Gym. sp., Gymnodinium sp.; Ast. for., Asterionella formosa; Cry. ero., Cryptomonas erosa; Sno. lac., Snowella lacustris; Ste. par., Stephanodiscus parvus; Chr. par., Chrysochromulina parva; Cyc. sp., Cyclotella sp.; Cry. sp., Cryptomonas sp.; Aph. flo., Aphanothece floccosa; Uro. ame., Uroglena americana; Din. soc., Dinobryon sociale; Chroo. sp., Chroococcus sp.; Sph. sch., Sphaerocystis schroeteri; Gym. hel., Gymnodinium helveticum; Mon. cir., Monoraphidium circinale; Mon. con., Monoraphidium contortum; Ochro. sp., Ochromonas sp.; Aph. sp., Aphanocapsa sp.; Aph. del., Aphanocapsa delicatissima; Cyc. pra., Cyclotella praetermissa; Tha. pse., Thalassiosira pseudonana; Cyc. com./gor., Cyclotella comensis/gordonensis; Tab. flo., Tabellaria flocculosa; Per. wil., Peridinium willei.

\begin{tabular}{|c|c|c|c|c|c|c|}
\hline & $\begin{array}{c}\text { Winter } \\
\text { (jan-hmar) }\end{array}$ & $\begin{array}{l}\text { Early Spring } \\
\text { (hmar-hmay) }\end{array}$ & $\begin{array}{l}\text { Late Spring } \\
\text { (hmay-june) }\end{array}$ & $\begin{array}{l}\text { Early Summer } \\
\text { (july) }\end{array}$ & $\begin{array}{l}\text { Late Summer } \\
\quad \text { (aug-sep) }\end{array}$ & $\begin{array}{l}\text { Autumn } \\
\text { (oct-dec) }\end{array}$ \\
\hline 1995 & $\begin{array}{c}\text { Pla. rub. } \\
\text { Osc. lim. } \\
\text { Aul.isl.hel. } \\
\underline{\text { Lim. sp. }} \\
\text { Mal. cau. } \\
\text { Aul. amb. } \\
\text { Cer. hir. } \\
\text { Rho. min. } \\
\text { Rho. lac. } \\
\text { Rhi. eri. } \\
\text { Dia. ten. }\end{array}$ & $\begin{array}{l}\text { Pla. rub. } \\
\text { Dia. ten. } \\
\text { Osc. lim. } \\
\frac{\text { Aul.isl.hel. }}{\text { Cer. hir. }} \\
\text { Aul. amb. } \\
\text { Fra. cro. } \\
\text { Mou. sp. }\end{array}$ & $\begin{array}{l}\text { Pla. rub. } \\
\text { Fra. cro. } \\
\text { Dia. ten. } \\
\text { Osc. lim. }\end{array}$ & $\begin{array}{l}\text { Pla. rub. } \\
\text { Dia. ten. } \\
\text { Fra. cro. } \\
\text { Osc. lim. } \\
\text { Mou. sp. }\end{array}$ & $\begin{array}{l}\text { Dia. ten. } \\
\text { Cer. hir. } \\
\text { Osc. lim. } \\
\text { Mou. sp. } \\
\text { Fra. cro. } \\
\text { Aph. cla. } \\
\text { Cyc. com. } \\
\text { Gym. sp. }\end{array}$ & $\begin{array}{l}\text { Ast. for. } \\
\text { Pla. rub. } \\
\text { Dia. ten. } \\
\text { Gym. hel. } \\
\text { Cry. ero. } \\
\text { Cer. hir. } \\
\text { Fra. cro. } \\
\text { Mou. sp. } \\
\text { Osc. lim. } \\
\text { Sno. lac. } \\
\text { Rho. min. }\end{array}$ \\
\hline 1996 & $\begin{array}{l}\text { Pla. rub. } \\
\text { Cer. hir. } \\
\text { Ast. for. } \\
\underline{\text { Rho. lac. }} \\
\underline{\text { Rho. min. }} \\
\underline{\text { Ste. par. }} \\
\text { Aul.isl.hel. } \\
\text { Mou. sp. } \\
\text { Fra. cro. } \\
\text { Chr. par. }\end{array}$ & $\begin{array}{l}\text { Fra. cro. } \\
\text { Dia. ten. } \\
\text { Ast. for. } \\
\text { Pla. rub. } \\
\text { Aul.isl.hel. } \\
\text { Osc. lim. }\end{array}$ & $\begin{array}{l}\text { Pla. rub. } \\
\text { Cyc. com. } \\
\text { Mou. sp. } \\
\text { Osc. lim. } \\
\text { Cer. hir. } \\
\text { Fra. cro. } \\
\text { Rho. min. } \\
\text { Chr. par. } \\
\text { Dia. ten. } \\
\text { Cyc. sp. }\end{array}$ & $\begin{array}{l}\text { Osc. lim. } \\
\text { Dia. ten. } \\
\text { Rhi. eri. } \\
\text { Fra. cro. } \\
\text { Cyc. com. } \\
\text { Pla. rub. } \\
\text { Gym. sp. } \\
\text { Chr. par. }\end{array}$ & $\begin{array}{l}\text { Osc. lim. } \\
\text { Cya. pla. } \\
\text { Cyc. com. } \\
\text { Cer. hir. } \\
\text { Cry. sp. } \\
\text { Aph. flo. } \\
\text { Pla. rub. } \\
\text { Lim. sp. }\end{array}$ & $\begin{array}{l}\text { Dia. ten. } \\
\text { Pla. rub. } \\
\text { Osc. lim. } \\
\text { Sno. lac. } \\
\text { Rhi. eri. } \\
\text { Gym. hel. } \\
\text { Fra. cro. }\end{array}$ \\
\hline 1997 & $\begin{array}{l}\text { Osc. lim. } \\
\text { Ast. for. } \\
\text { Rhi. eri. } \\
\text { Pla. rub. } \\
\text { Rho. min. } \\
\text { Rho. lac. } \\
\text { Chr. par. } \\
\text { Dia. ten. }\end{array}$ & $\begin{array}{l}\text { Dia. ten. } \\
\text { Aul. isl. hel. } \\
\text { Osc. lim. } \\
\text { Mou. sp. } \\
\text { Cyc. com. }\end{array}$ & $\begin{array}{l}\text { Osc. lim. } \\
\text { Mou. sp. } \\
\text { Rho. min. } \\
\text { Uro. ame. } \\
\text { Chr. par. } \\
\text { Cer. hir. } \\
\text { Din. soc. }\end{array}$ & $\begin{array}{l}\text { Rho. min. } \\
\text { Cer. hir. } \\
\text { Cry. sp. } \\
\text { Chr. par. } \\
\text { Gym. hel. } \\
\text { Chroo. sp. } \\
\text { Sph. sch. }\end{array}$ & $\begin{array}{l}\text { Aph. cla. } \\
\text { Fra. cro. } \\
\text { Cer. hir. } \\
\text { Aph. flo. } \\
\text { Cyc. com. } \\
\text { Gym. sp. }\end{array}$ & $\begin{array}{l}\text { Rho. min. } \\
\text { Gym. hel. } \\
\text { Cer. hir. } \\
\text { Rho. lac. } \\
\text { Aph. cla. } \\
\text { Ast. for. } \\
\text { Pla. rub. }\end{array}$ \\
\hline 1998 & $\begin{array}{l}\text { Ast. for. } \\
\text { Cyc. sp. } \\
\text { Ste. par. } \\
\text { Chr. par. } \\
\text { Mon. cir. } \\
\text { Rho. min. } \\
\text { Ochro. sp. } \\
\text { Mon. con. }\end{array}$ & $\begin{array}{l}\text { Lim. sp. } \\
\text { Fra. cro. } \\
\text { Aph. sp. } \\
\text { Ast. for. } \\
\text { Ochro. sp. } \\
\text { Cyc. sp. } \\
\text { Aph. cla. } \\
\text { Mon. con. }\end{array}$ & $\begin{array}{l}\text { Aph. sp. } \\
\text { Lim. sp. } \\
\text { Aph. del. } \\
\text { Aph. cla. } \\
\text { Pla. rub. } \\
\text { Cyc. sp. }\end{array}$ & $\begin{array}{l}\text { Aph. cla. } \\
\text { Aph. flo. } \\
\text { Aph. del. } \\
\text { Pla. rub. } \\
\text { Aph. sp. } \\
\text { Cyc. pra. }\end{array}$ & $\begin{array}{l}\text { Aph. cla. } \\
\text { Aph. flo. } \\
\text { Aph. del. } \\
\text { Pla. rub. } \\
\text { Aph. sp. } \\
\text { Cyc. pra. }\end{array}$ & $\begin{array}{l}\text { Pla. rub. } \\
\text { Rho. min. } \\
\text { Tha. pse. } \\
\text { Aph. sp. } \\
\text { Ochro. sp. } \\
\text { Sno. lac. } \\
\text { Chr. par. }\end{array}$ \\
\hline 1999 & $\begin{array}{l}\text { Cyc. com./gor. } \\
\text { Rho. min. } \\
\text { Pla. rub. } \\
\text { Aul. isl. hel. } \\
\text { Fra. cro. } \\
\text { Ast. for. } \\
\text { Rho. lac. }\end{array}$ & $\begin{array}{l}\text { Aul. isl. hel. } \\
\text { Cyc. com./gor. } \\
\text { Fra. cro. } \\
\begin{array}{l}\text { Ast. for. } \\
\text { Cyc. com./gor. }\end{array}\end{array}$ & $\begin{array}{l}\text { Ast. for. } \\
\text { Tab. flo. } \\
\text { Fra. cro. } \\
\text { Aul. isl. hel. }\end{array}$ & $\begin{array}{l}\text { Tab. flo. } \\
\text { Fra. cro. } \\
\text { Pla. rub. } \\
\text { Rho. min. } \\
\text { Chr. par. } \\
\text { Cry. sp. } \\
\text { Dia. ten. } \\
\text { Gym. hel. }\end{array}$ & 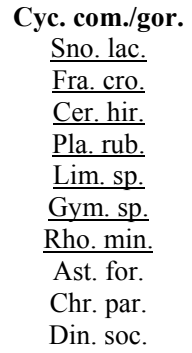 & $\begin{array}{l}\text { Mal. cau. } \\
\text { Pla. rub. } \\
\text { Rho. min. } \\
\text { Fra. cro. } \\
\text { Cer. hir. } \\
\text { Cry. ero. } \\
\text { Gym. hel. } \\
\text { Per. wil. } \\
\text { Cyc. com./gor. } \\
\text { Sno. lac. }\end{array}$ \\
\hline
\end{tabular}


Tab. 3. Phytoplankton associations in Lago Maggiore (1995-1999), corresponding to the main sequence of the seasonal succession. Abbreviations of species as in table 2 .

\begin{tabular}{|c|c|c|c|c|c|}
\hline $\begin{array}{c}\text { Winter } \\
\text { (Jan-hMar) }\end{array}$ & $\begin{array}{c}\text { Early Spring } \\
\text { (hMar-hMay) }\end{array}$ & $\begin{array}{c}\text { Late Spring } \\
\text { (hMay-June) }\end{array}$ & $\begin{array}{l}\text { Early Summer } \\
\text { (July) }\end{array}$ & $\begin{array}{l}\text { Late Summer } \\
\text { (Aug-Sep) }\end{array}$ & $\begin{array}{c}\text { Autumn } \\
\text { (Oct-Dec) }\end{array}$ \\
\hline $\begin{array}{c}\text { Pla. rub. } \\
\text { Osc. lim. } \\
\text { Ast. for. } \\
\text { Rho. min. } \\
\text { Rho. lac. } \\
\text { Aul.isl.hel. } \\
\text { Chr.par. }\end{array}$ & $\begin{array}{c}\text { Dia. elo. } \\
\text { Aul.isl.hel. } \\
\text { Ast. for. } \\
\text { Fra. cro. } \\
\text { Cer. hir. } \\
\text { Cyc. com. }\end{array}$ & $\begin{array}{l}\text { Pla. rub. } \\
\text { Fra. cro. } \\
\text { Chr. par. } \\
\text { Osc. lim. } \\
\text { Mou. sp. } \\
\text { Rho. min. }\end{array}$ & $\begin{array}{l}\text { Pla. rub. } \\
\text { Fra. cro. } \\
\text { Cyc. com. } \\
\text { Chr. par. }\end{array}$ & $\begin{array}{c}\text { Cer. hir. } \\
\text { Aph. spp. } \\
\text { Cyc. com. } \\
\text { Pla. rub. }\end{array}$ & $\begin{array}{l}\text { Pla. rub. } \\
\text { Rho. min. } \\
\text { Gym. hel. } \\
\text { Cer. hir. } \\
\text { Fra. cro. } \\
\text { Sno. lac. }\end{array}$ \\
\hline
\end{tabular}

Low rainfall was recorded thereafter, but in March 1999 the monthly average was the highest measured during this month over the whole five-year period. The rainfall of spring 1999 was also quite high, but in the range of the spring values recorded since 1995. After a summer period of scarce precipitation, in September the yearly peak was recorded, then the values decreased until the end of the year.

The seasonal fluctuations of the solar radiation are also responsible for the variability of the water temperature in the course of the year. A clear indication of this close relationship is given in figure 2. A change in the amount of the incident solar radiation determines a change in the surface water temperature with a delay of about one month. During 1997 this causal relationship is particularly clear: in fact, the high values of water temperature during spring, late summer (max over $24{ }^{\circ} \mathrm{C}$ in August) and autumn are probably due to the high amount of incident solar radiation, whereas the strong decline of radiation in June can explain the cooling of the surface waters during July down to $16.5{ }^{\circ} \mathrm{C}$. The years 1995 and 1996 show a similar seasonal evolution of the water temperature, with average values lower than 1997 in every season. During spring 1998 the surface waters reached quite high temperatures, comparable to those recorded during spring 1997, but from July to December the temperature trend was more similar to that of 1995-'96, with values lower than during 1997. The year 1999 is characterised by a spring period with surface temperature slightly lower, because of the February complete overturn (see next paragraph): the surface waters remained colder even during the early summer, reaching the maximum value in August, then maintained slightly higher values during the autumn months, with respect to the period 1995-1998.

\subsection{Thermal seasonal regime}

Lago Maggiore is a warm monomictic lake, sensu Hutchinson (1957): however, according to Ambrosetti \& Barbanti (1997), the lake can be classified as olo-oligomictic, because, due to its high depth, a complete overturn takes place only during the coldest and most windy winters. During February 1999 and 2000 Lago Maggiore underwent a complete overturn, an event which is rarely observed: before 1999 the previous complete overturn took place in 1971. During winter circulation events, the mixing depth usually reaches 100-150 m (Ambrosetti \& Barbanti 1997). Figure 3 reports the seasonal course of the water column temperature in the years 1998 and 1999: the first year exemplifies the commonest situation, and the second one what occurs during a full mixing year. Since the end of May the lake is thermally stratified and it is possible to identify an epilimnetic layer, where the maximum surface temperature can reach $21-22{ }^{\circ} \mathrm{C}$ during August $\left(24{ }^{\circ} \mathrm{C}\right.$ in 1997), and a metalimnetic layer, located between 10 and $15 \mathrm{~m}$ depth. In September the thermocline moves down to about $20 \mathrm{~m}$ depth as water cools down, then gradually disappears. The winter mixing usually takes place in February. During February 1999 a full mixing of short duration took place: the most significant effects recorded on the planktonic communities were a strong depletion of the organisms in the euphotic layer, as they were redistributed over a $370 \mathrm{~m}$ deep water column. A refuelling of "new" algal nutrients to surface waters, stimulated the spring productivity. However, no further effect of the full mixing was observed during the rest of the year, as documented by Manca et al. (2000).

\subsection{Light seasonal regime}

During 1998 and 1999 we calculated the depth of the euphotic zone $\left(Z_{\text {eu }}\right)$, defined as the depth where the incident PAR falls down to $1 \%$ of the surface value, by radiometric measurements of the underwater PAR attenuation. The euphotic layer varied from about $25 \mathrm{~m}$ depth in winter months to $10-15$ meters in summer. Following Kirk (1994) the values of the vertical light attenuation coefficient $\left(\mathrm{K}_{\mathrm{d}}\right)$ were calculated as the slope of the exponential relationship between incident PAR radiation $\left(\mathrm{I}_{\mathrm{o}}\right)$ and underwater PAR measured at each single depth $\left(\mathrm{I}_{\mathrm{z}}\right)$. During 1998 and $1999 \mathrm{~K}_{\mathrm{d}}$ fluctuated in the range $0.1-0.5 \mathrm{~m}^{-1}$, values commonly found in clear lakes (Kirk 1994).

For both years, a relationship between chlorophyll- $a$ concentration in the euphotic layer and $\mathrm{K}_{\mathrm{d}}$ showed that in Lago Maggiore a significant amount of the light attenuation is due to non phytoplanktonic material, being the intercept of the regression equation around $0.2 \mathrm{~m}^{-1}$. Moreover, this relationship showed an uncoupling between the seasonal trends of chlorophyll, $\mathrm{K}_{\mathrm{d}}$ and trans- 


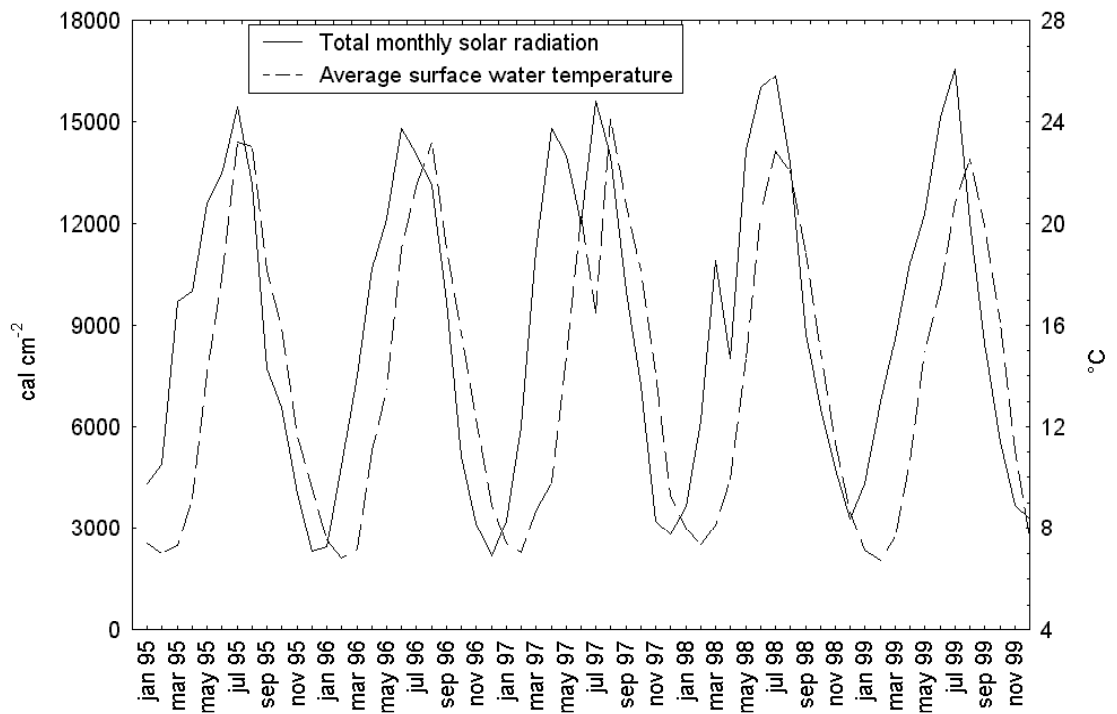

Fig. 2. Monthly values of the total incident solar radiation and average surface water temperature.

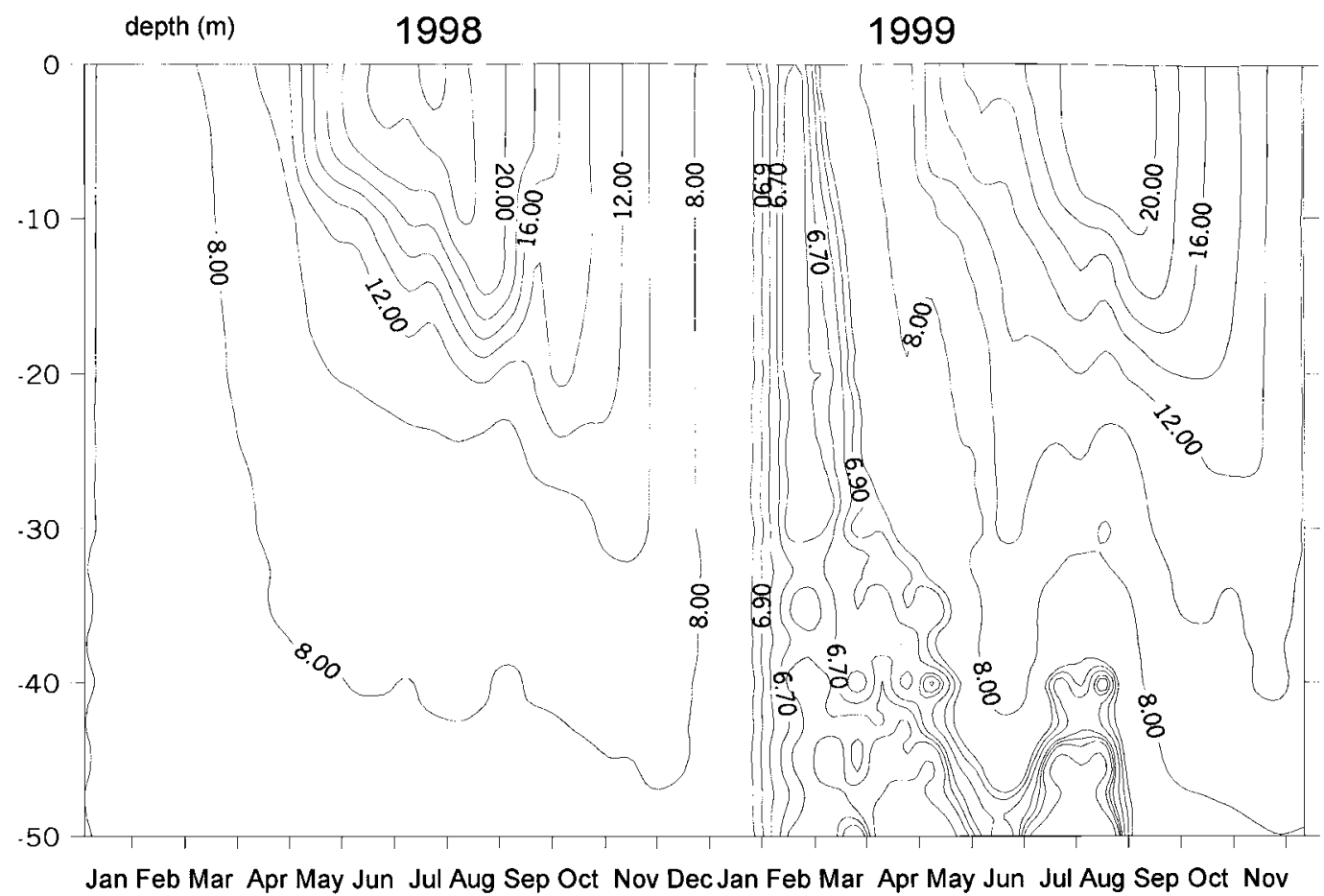

Fig. 3. Seasonal evolution of the thermal regime in Lago Maggiore (1998-1999).

parency measured as Secchi depth, indicating that euphotic chlorophyll- $a$ concentration cannot reliably be used to estimate the depth of the euphotic zone.

A good relationship also exists between Secchi depth (SD) and euphotic zone depth $\left(Z_{\text {eu }}\right)$, so that transparency can be used to estimate the depth of the euphotic layer, according to the following equation derived from the data collected during 1998 and 1999:

$$
\mathrm{Z}_{\mathrm{eu}}=6.995 \mathrm{SD}^{0.743}
$$

$(\mathrm{R}=0.733 ; \mathrm{n}=38$; explained variance $53.8 \%)$

\section{CHEMICAL ENVIRONMENT}

The trends of the main chemical parameters for the period $1996-1999$ are reported in the figures 4-5. Year 1995 has not been included in the graphs, because only 

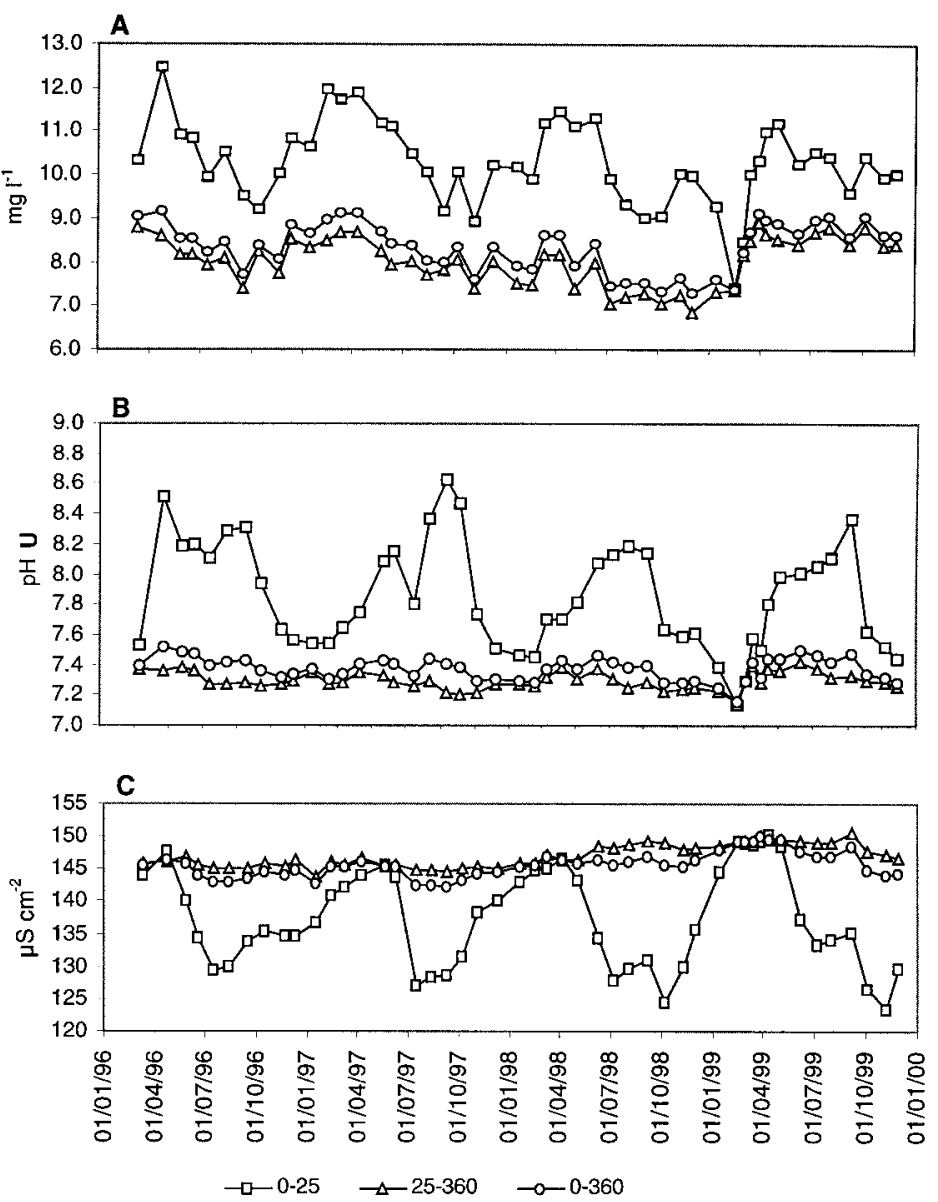

Fig. 4. Seasonal fluctuations of dissolved oxygen (A), pH (B) and conductivity (C) in the water column of Lago Maggiore (19961999).

four samples were taken during that year for chemical analysis. The seasonal pattern of oxygen and $\mathrm{pH}$ in the surface waters was typical, paralleling the fluctuations of the phytoplankton photosynthetic activity, i.e. with the minimum values in autumn and winter and the maxima in summer. In the deeper layers such fluctuations are also present, but very smoothed. The effect of the winter mixing can be seen in the attenuation of the differences between epilimnetic and hypolimnetic values, but a complete homogenisation of the values along the whole water column took place only during the full mixing in 1999.

The conductivity values, decreased in summer months, due to carbonate precipitation, caused by the algal $\mathrm{CO}_{2}$ depletion. It should be noted the gradual increase in conductivity in the bottom layers, due to the deep accumulation of solutes, which was broken down by the complete overturn of February ' 99.

The trend of nitrate nitrogen in the surface waters is probably related to the algal consumption: after the replenishment of the epilimnetic waters with mixing, when nitrate reaches about $850 \mu \mathrm{g}^{-1}$, its concentration decreased from spring to the end of summer, when the annual minimum values of around $550 \mu \mathrm{g}^{-1}$ are usually recorded. With these values, a nitrogen limitation can be excluded in Lago Maggiore. The hypolimnetic values are stable, fluctuating between 800 and $850 \mu \mathrm{g} \mathrm{l}^{-1}$.

Epilimnetic reactive silica fluctuates in the range 0.4 - $1.4 \mathrm{mg} \mathrm{l}^{-1}$, following an usual pattern, dependent on the consumption by diatoms and on the supply by winter mixing. In the bottom layers the variations are very smoothed and the concentration remains quite stable around $0.5 \mathrm{mg} \mathrm{l}^{-1}$.

Epilimnetic reactive phosphorus is always very low, with values around $3 \mu \mathrm{g} \mathrm{l}^{-1}$ during the whole year, often close to detection limit of the analytical method used. Exceptionally, during the complete overturn of winter 1999 a peak of $8 \mu \mathrm{g} \mathrm{l}^{-1}$ was recorded. A concentration between 6 and $8 \mu \mathrm{g} \mathrm{l}^{-1}$ usually characterise the hypolimnetic water layers. The epilimnetic concentration of total phosphorus never exceeded $10 \mu \mathrm{g}^{-1}$, except during the 1999 overturn, when this parameter reached $14 \mu \mathrm{g} \mathrm{l}^{-1}$. The fluctuations of phosphorus do not seem to be related to the algal consumption and, in general, no clear temporal trend is recognizable. 

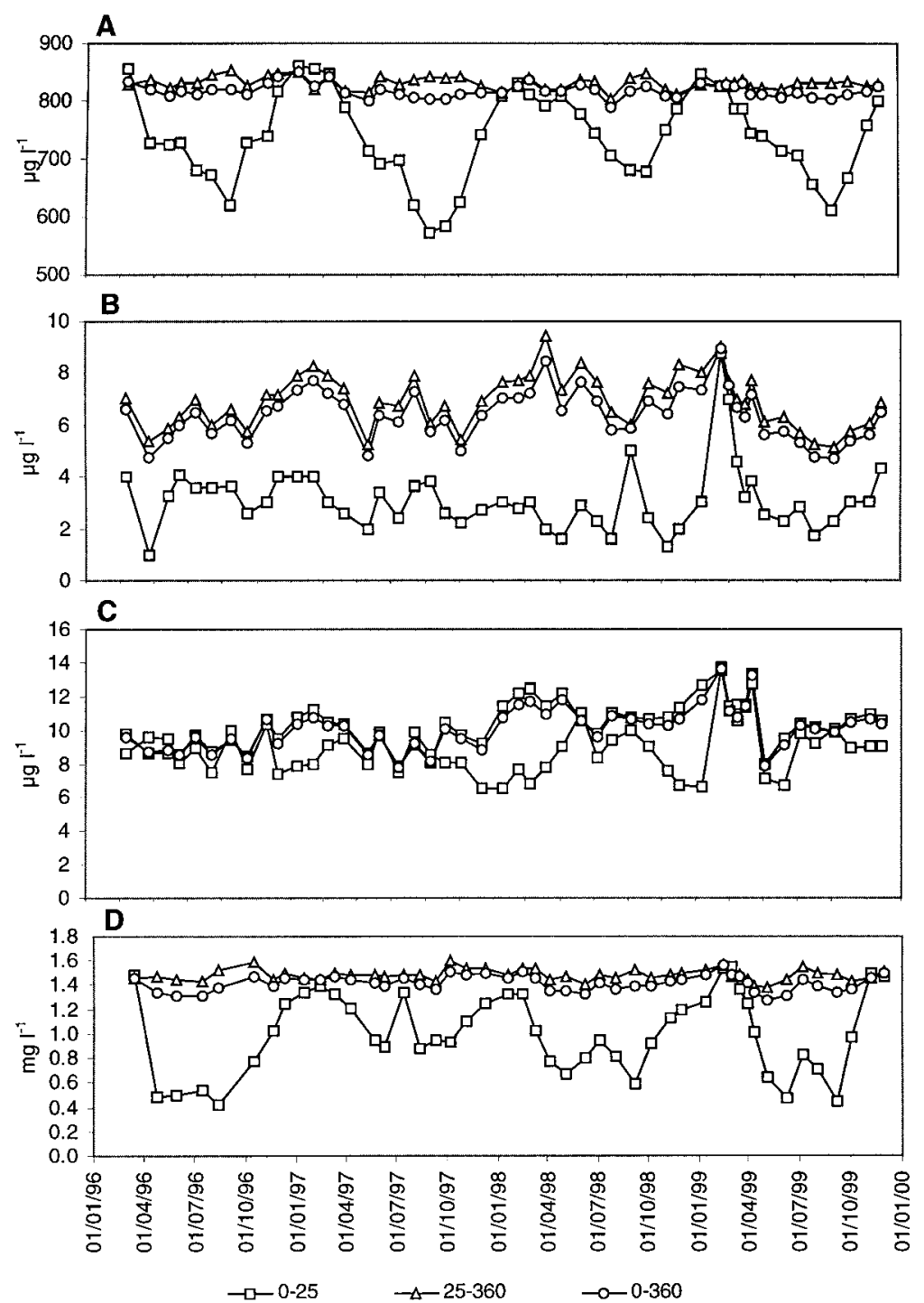

Fig. 5. Seasonal fluctuations of nitrate nitrogen $(\mathbf{A})$, reactive phosphorus $(\mathbf{B})$ total phosphorus $(\mathbf{C})$ and reactive silica $(\mathbf{D})$ in the water column of Lago Maggiore (1996-1999).

\section{PHYTOPLANKTON ASSOCIATIONS (1995 - 1999)}

In Lago Maggiore the two dominant algal groups by biovolume are Cyanoprokaryota and Bacillariophyceae, as shown in figure 6 . The first group is present during the whole seasonal cycle, and reaches the highest importance in summer. The diatoms are usually dominant in spring, when the mixing depth is great enough to counteract their sedimentary losses. Peaks of diatoms are also recorded during summertime, mainly located at the metalimnetic layer, where the temperature gradient can slow down their sedimentation.

The phytoplankton succession was quite uniform from year to year. Some differences were due to the variable relative importance of each single algal group. For instance, the contribution of the Cyanoprokaryota declined during the last two years. Among the others, Chrysophyceae, Cryptophyceae and Dinophyceae can be sub-dominant during the whole seasonal cycle, whereas high Chlorophyta biovolumes are usually limited to the summer season.

The cluster analysis performed on the whole data set shows a clear separation of the samples collected during 1998 and 1999 from the remaining samples (Fig. 7), a fact possibly explained by the mentioned reduction of the Cyanoprokaryota. However, it should be pointed out that the 1998 samples form a single cluster at the highest hierarchical level, whereas the 1999 samples are more like those of the period 1995-'97. Although the general pattern of the seasonal succession appears to be very similar during the last two years (see Fig. 6), the different seasonal dynamics of the algal groups can explain the segregation of the 1998 samples. In fact, dur- 


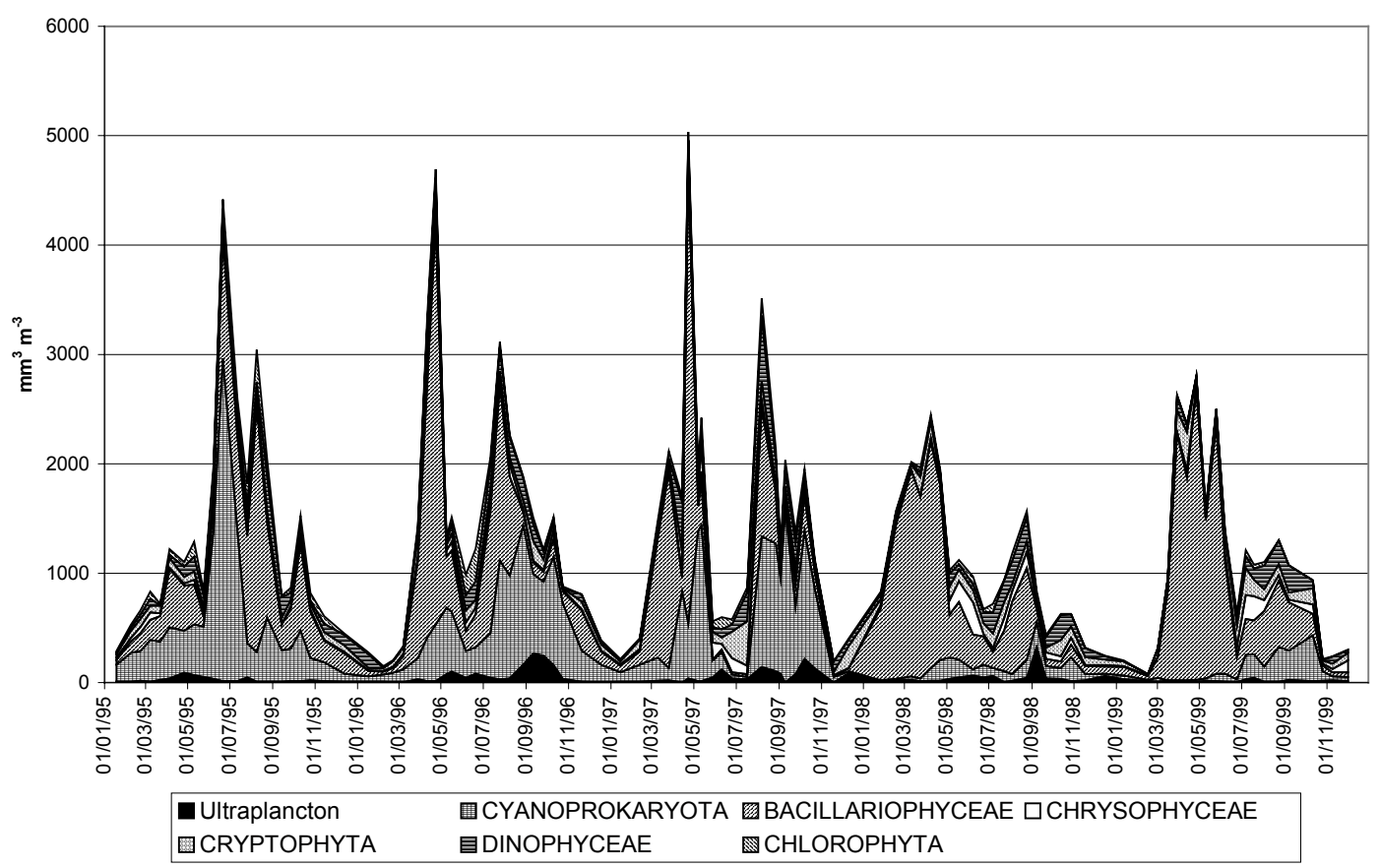

Fig. 6. Seasonal development of the biovolume of the main algal groups in the period 1995-1999.

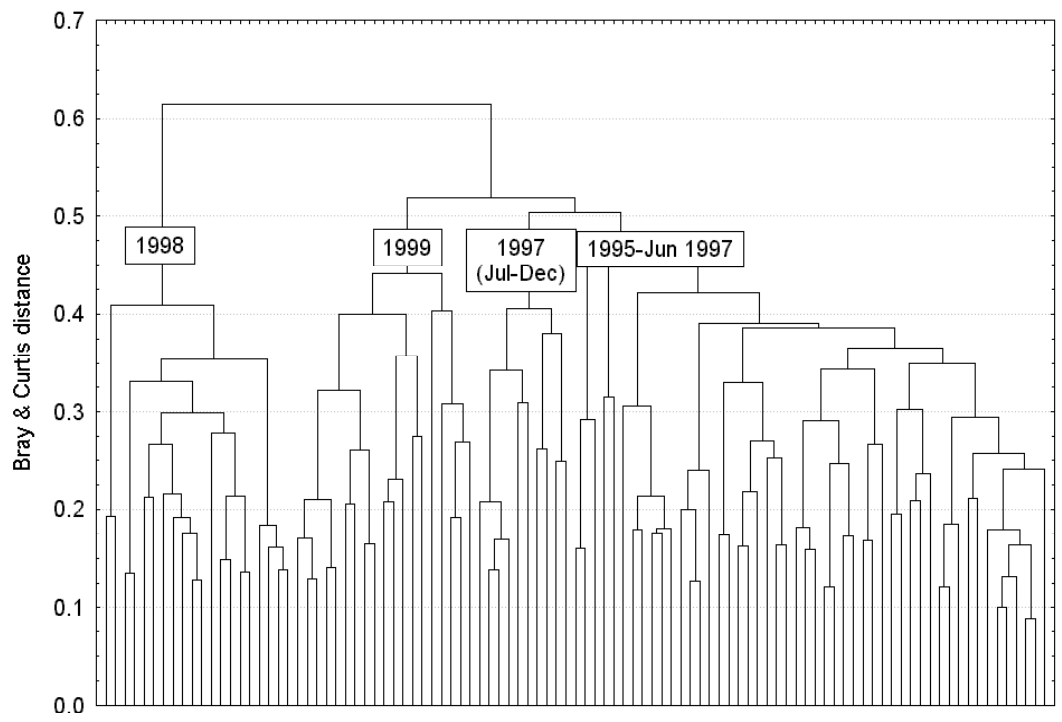

Fig. 7. Clustering of all the samples according to the calculation of the Bray-Curtis similarity index. See text for further explanations.

ing 1998 diatoms declined earlier than in 1999, leaving place to the development of other groups (Chrysophyceae, Cryptophyceae, Dinophyceae). Moreover, in July 1998 the Chrysophyceae declined, whereas during 1999 this group was very important in the same month. Lower values of the biomass of Cyanoprokaryota and a different dynamics of this group also contributed to the separation of the year 1998 from the others.

The dynamics of the algal assemblages can be better understood through a fine analysis of each single year. The results of the cluster analysis enabled us to divide each yearly data set into seasonal clusters, identified as explained in Section 3. The species associations characterising each seasonal period from 1995 to 1999 are described below. Figure 8 show the seasonal fluctuations of the species characterising the assemblages recognised for the study period 1995-1999.

\subsection{Winter}

As explained in Section 3, the season called Winter (W) includes the samples collected from January to half-March. The 1995 Winter assemblage is dominated 

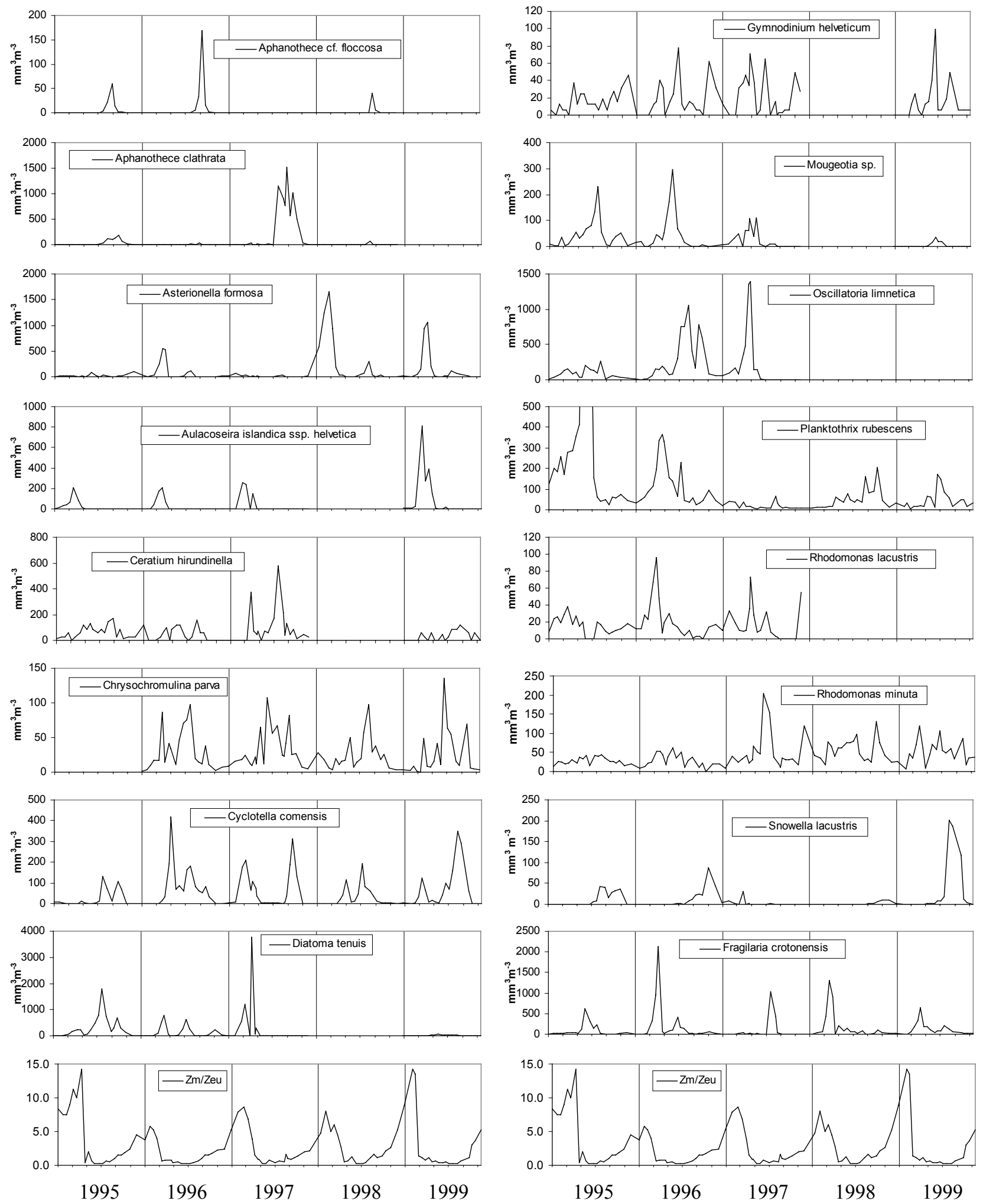

Fig. 8. Seasonal development of the dominant species and of mixing depth $v s$ euphotic depth $\left(\mathrm{Z}_{\mathrm{m}} / \mathrm{Z}_{\mathrm{eu}}\right)$.

by Planktothrix rubescens and Oscillatoria limnetica, reaching together more than $40 \%$ of the total biovolume. Sub - dominant species (between $5 \%$ and $10 \%$ of the total biovolume) are Aulacoseira islandica morf. helvetica and Limnothrix sp. Rhodomonas minuta, $R$. lacustris, Ceratium hirundinella, Rhizosolenia eriensis 
v. morsa and Diatoma tenuis are the remaining species contributing to made up $80 \%$ of the total community biomass.

During Winter 1996 Planktothrix rubescens is again dominant, together with Ceratium hirundinella. Asterionella formosa, Stephanodiscus parvus, Rhodomonas minuta and $R$. lacustris are sub-dominant. Other important species are listed in table 2.

The Oscillatoriales (Planktothrix rubescens and Oscillatoria limnetica) also dominated the 1997 Winter assemblage, together with Asterionella formosa and Rhizosolenia eriensis and with the two Rhodomonas species as sub - dominants. Chrysochromulina parva and Diatoma tenuis gave also an important contribution to the $80 \%$ biovolume.

During Winter 1998 the phytoplankton assemblage was dominated by diatoms: Asterionella formosa, Cyclotella sp. and Stephanodiscus parvus amounted to about $50 \%$ of the total biovolume. Among the dominant species Chrysochromulina parva is also important (around 10\% biovolume). Rhodomonas minuta, Monoraphidium circinale and Ochromonas sp. were the sub-dominant species.

In Winter 1999 Planktothrix rubescens was dominant again, together with Cyclotella comensis/gordonensis and Rhodomonas minuta. In the range 5 - $10 \%$ biovolume we found Aulacoseira islandica morf. helvetica, Fragilaria crotonensis and Asterionella formosa.

By comparing the five winter phytoplankton cluster as described in the methods section, we identified a group of species which we may call, at least provisionally, the "Winter phytoplankton association" in Lago Maggiore (see Tab. 3): this assemblage is dominated (biovolume greater than $10 \%$ ) by the Cyanoprokaryota Planktothrix rubescens and Oscillatoria limnetica and by the diatom Asterionella formosa; the most common sub-dominant species (biovolume between 5 and 10\%) are Rhodomonas minuta and R. lacustris, Aulacoseira islandica morf. helvetica, Chrysochromulina parva.

\subsection{Early Spring}

The season named Early Spring (ESP) includes the samples collected from half-March to half-May.

During ESP 1995 Planktothrix rubescens and Diatoma tenuis were the dominant species, Oscillatoria limnetica, Aulacoseira islandica morf. helvetica, Ceratium hirundinella the sub-dominant.

In 1996 the ESP assemblage was dominated by the pennate diatoms, in particular Fragilaria crotonensis, Diatoma tenuis, Asterionella formosa. Planktothrix rubescens was the most important sub - dominant. However, it must be noted that inside this assemblage some changes, towards a species composition closer to that of the Late Spring period, took place earlier than in other years: this may depend on the fact that the period February - April 1996 was characterised by unusual mete- orological conditions, with rain and wind lower than the average monthly values recorded since 1978 for rain (Libera \& Carollo 1997) and since 1957 for wind (Ambrosetti et al. 1997) respectively. An anticipated warming of the water during April probably stimulated an earlier growth and decline of the diatoms, contributing, during May, to the establishment of species usually found later in the year, typically Oscillatoria limnetica and Cyclotella cf. comensis.

The phytoplankton dynamics during ESP 1997 is more complicated: in March samples Diatoma tenuis, Aulacoseira islandica morf. helvetica and Oscillatoria limnetica were the dominant species, with Mougeotia sp. and Cyclotella comensis sub - dominants. However, during April a shift in the species composition took place: the diatoms declined and were replaced by Ceratium hirundinella (dominant with Oscillatoria limnetica) and by Cyanodictyon planctonicum, Cryptomonas sp. and Aphanothece floccosa as sub - dominants. In May the succession pattern reverted towards the dominance of Diatoma tenuis, which amounted to more than $40 \%$ of the total biovolume. Oscillatoria limnetica was also important ( $34 \%$ as biovolume). The reasons for the April shift are not clear: no changes in nutrient concentration nor in water temperature can be claimed as possible causes. An exceptionally high incident solar radiation was recorded during April 1997, even though the effect on the water temperature became evident only during May. However, the progressive warming of the water column could have favoured the development of herbivorous zooplankton: in fact, during April 1997 the copepod population reached the highest abundance values for the period 1995 - 1998 (Manca et al. 1998). The temporary shift in the species composition could be, at least in part, due to an increased grazing pressure.

During ESP 1998 Limnothrix sp. and Fragilaria crotonensis were the dominant species and Aphanothece sp. and Asterionella formosa the most important sub dominants.

ESP 1999 was fully dominated by the diatoms, in particular by Aulacoseira islandica morf. helvetica and Cyclotella comensis/gordonensis as dominants, together with Fragilaria crotonensis and Asterionella formosa as sub-dominants.

The analysis of the species assemblages recorded during the five years enabled us to identify one characterising the Early Spring, dominated by the pennate diatoms, mainly with Diatoma tenuis, Aulacoseira islandica morf. helvetica, Fragilaria crotonensis and Asterionella formosa. Ceratium hirundinella and Cyclotella comensis can be important as sub-dominants species (Tab. 3).

\subsection{Late Spring}

Under the term Late Spring (LSP) we included the samples collected from half-May to the end of June. Late Spring 1995 is characterised by an almost complete 
dominance of Planktothrix rubescens $(62 \%$ of total community biovolume), together with Fragilaria crotonensis.

In 1996 Planktothrix rubescens was again recorded among the dominant species, which also included $C y$ clotella comensis, Mougeotia sp. and Oscillatoria limnetica. Ceratium hirundinella and Fragilaria crotonensis were sub-dominants. Some other species contributed to build up $80 \%$ of the total biovolume (Tab. 2).

Oscillatoria limnetica and Mougeotia sp. were again dominant during 1997, together with Rhodomonas minuta, Uroglena americana, Chrysochromulina parva and Ceratium hirundinella as sub-dominants.

LSP 1998 is dominated by Cyanoprokaryota (Aphanothece sp., Limnothrix sp., Aphanocapsa delicatissima, Aphanothece clathrata), whereas during 1999 the association is dominated by diatoms (Asterionella formosa, Tabellaria flocculosa, Fragilaria crotonensis and Aulacoseira islandica morf. helvetica).

By comparing the clusters related to Late Spring we could distinguish the following association (Tab. 3): Planktothrix rubescens and Fragilaria crotonensis as dominant species, Chrysochromulina parva, Oscillatoria limnetica, Mougeotia sp. and Rhodomonas minuta as sub-dominant.

\subsection{Early Summer}

Apparently, a shift of the assemblage composition from Late Spring to Late Summer association often occurs in July, as shown by the separate clustering of the samples collected in July. Because of this kind of clustering, the July samples only were selected to represent the seasonal period called Early Summer (ESU). In fact, the assemblage recorded during July can be, in most cases, a mixing of the species present during both spring and late summer. For instance, diatoms, typically a spring group, can be still important, as has been observed in July 1995, 1996 and 1999, when Diatoma tenuis, Fragilaria crotonensis, Rhizosolenia eriensis v. morsa, Cyclotella comensis and Tabellaria flocculosa were recorded as dominant or sub-dominant species (see Tab. 2). Together with diatoms, the blue- greens Planktothrix rubescens and Oscillatoria limnetica were dominant or sub-dominant during ESU 1995, 1996 and 1999. Two years (1997 and 1998) showed quite different associations during July: the first was dominated by species more typical of colder periods, such as Rhodomonas minuta and Cryptomonas sp. (together with Ceratium hirundinella and Chrysochromulina parva), probably in part dependent on the strong decrease of the water temperature in July 1997 (see Fig. 2). The assemblage of July 1998 was dominated, on the other hand, by Cyanoprokaryota, mainly Chroococcales (Aphanothece clathrata, A. floccosa, Aphanocapsa delicatissima). On the whole five year period, the July assemblage was highly variable from year to year, probably because it represents a transitional phase during the seasonal suc- cession pathway. Due to this reason, only four species can be recognised as distinctive members of the ESU association: Planktothrix rubescens and Fragilaria crotonensis as dominants; Cyclotella comensis and Chrysochromulina parva as sub-dominant.

\subsection{Late Summer}

Late Summer period (LSU includes August and September.

In 1995, these months were dominated by Diatoma tenuis, with Ceratium hirundinella and Oscillatoria limnetica as sub-dominant species.

Oscillatoria limnetica became the dominant species during summer 1996, being Cyanodictyon planctonicum and Cyclotella comensis the sub-dominants.

During August and September 1997 and 1998 the Chroococcales became the most important algae: Aphanothece clathrata dominated during 1997, with Aphanothece floccosa sub-dominant, whereas during 1998 both species were dominant together with Aphanocapsa delicatissima. During late summer 1997 Fragilaria crotonensis and Ceratium hirundinella too reached a biomass higher than $10 \%$ of the total.

Cyclotella comensis was the dominant species during LSU 1999: many species were sub-dominant, such as Snowella lacustris, Fragilaria crotonensis, Ceratium hirundinella, Planktothrix rubescens (see Tab. 2). As during ESU, the years 1997 and 1998 exhibited very similar LSU assemblages, but different from those in 1995, 1996 and 1997. Because of this variability, we could distinguish only four taxa typical for the LSU association: the three most important, often included among the dominant or sub-dominant, are Cyclotella comensis, Ceratium hirundinella and Aphanothece (clathrata and/or floccosa). Moreover, due to its constancy, although never dominant and sometimes subdominant, Planktothrix rubescens too should be included in the LSU association.

\subsection{Autumn}

The samples collected from October to December were part of the Autumn (A) seasonal period. During October 1995 the phytoplankton assemblage exhibited intermediate features between a LSU and an Autumn association (see Tab. 2). Among the most important species was Aphanothece clathrata, whose growth was probably enhanced by a long period of moderate wind and scarce rainfall. The two following months (November and December) were dominated by Asterionella formosa, Planktothrix rubescens, Diatoma tenuis, with Gymnodinium helveticum, Cryptomonas erosa, Ceratium hirundinella and Fragilaria crotonensis as sub-dominant species.

In Autumn 1996 Diatoma tenuis and Planktothrix rubescens shared their dominant position with Oscillatoria limnetica and Snowella lacustris. The most important species in the biovolume range 5-10\%, were 
Rhizosolenia eriensis v. morsa, Gymnodinium helveticum and Fragilaria crotonensis.

Rhodomonas minuta, Gymnodinium helveticum, Ceratium hirundinella and Rhodomonas lacustris dominated the association A during 1997, with Aphanothece clathrata as sub-dominant.

The group of the dominant species was quite similar during Autumn 1998 and 1999: the two dominant species in 1998 (Planktothrix rubescens and Rhodomonas minuta) were again the most important in 1999, together with Mallomonas caudata and Fragilaria crotonensis. On the other hand, the sub-dominant species group was completely different: Thalassiosira pseudonana, Aphanothece sp., Ochromonas sp., Snowella lacustris and Chrysochromulina parva in 1998; Ceratium hirundinella alone during 1999.

In summary, from autumn 1995 to autumn 1999 the phytoplankton assemblage showed a smoothed variability, making easier the identification of an association dominated by Planktothrix rubescens, Rhodomonas minuta and Gymnodinium helveticum. Ceratium hirundinella, Fragilaria crotonensis and Snowella lacustris built up the group of sub-dominant species.

\section{DISCUSSION}

The phytoplankton communities of the deep southern subalpine lakes have been compared to each other in two previous studies (Ruggiu 1983; Ambrosetti et al. 1992): most of the species classified as dominant or sub-dominant in the present paper are the same already identified as common to this kind of lacustrine system; typically Planktothrix rubescens, Asterionella formosa, Fragilaria crotonensis, Aulacoseira islandica morf. helvetica, Rhodomonas minuta and lacustris, Ceratium hirundinella, Mougeotia sp. Other species, such as $C y$ clotella comensis and Chrysochromulina parva, became important only in the most recent years in Lago Maggiore, following the improvement of its trophic status.

The basic structure of the assemblages more recently described confirm the hypothesis made by Ruggiu (1983) that in deep southern subalpine lakes the phytoplankton composition is largely dependent on similar geographic, morphometric and hydrodynamic features, whereas the biomass level is mainly determined by the nutrient load. This confirmation coming from the last few years certainly represents a favourable starting point towards a possible identification of algal association patterns characterising these kind of lacustrine ecosystems. The analysis presented here enabled us to recognise the phytoplankton associations occurring in Lago Maggiore; however, the proven existence of a pool of species common to the whole lake district could have a wider application and consequently a wider significance for our findings.

In table 3 we reported the seasonal assemblages identified during the study period, whereas figures 8-9 show the seasonal development of single species. As previously explained, each seasonal period includes the months chosen on the basis of the samples clustering as resulting from the calculation of the Bray-Curtis similarity index. It is interesting to note that a similar periodicity has been suggested by Reynolds $(1980 ; 1984)$ and by Seip and Reynolds (1995) in relating the functional attributes of phytoplankton to the changes in the physical environment. This coincidence reinforces the possibility of a widespread application of our results.

The Winter association (Tab. 3) is made up by a set of $\mathrm{C}$ and $\mathrm{R}$ species, following the classification of lifestyle strategies proposed by Reynolds (1997) and is dominated by filamentous Oscillatoriales. This kind of cyanobacteria are typical representatives of two distinct Associations, named by Reynolds (1997) R and S respectively. The first, called Planktothrix rubescens/mougeotii, is typical of well stratified lakes, where the cyanobacteria form plate-like layers close to the metalimnion, while the second (S), characterised by Planktothrix agardhii/redekei, is very common in shallow, turbid and well mixed environments. However, it is nearly impossible to distinguish Planktothrix rubescens from Planktothrix agardhii by microscopic examination alone, so that they are usually joined together in the Planktothrix rubescens/agardhii group (e.g. Skulberg \& Skulberg 1985). Because of this, we cannot say whether the Planktothrix colonies recorded during winter belong to one or the other of the two species. The separation proposed by Reynolds (1997) on the basis of the respective ecological preferences does not help: in fact, although the mixed water column of the winter period should host the S-Association (the deep mixing could have the same effect as turbidity on the light climate experienced by the algae), these Winter Oscillatoriales could represent the inoculum for the successive growth of $P$. rubescens, as described by some authors (Walsby et al. 1998).

In this paper the Planktothrix filaments have been always ascribed to the rubescens species, as it was made in past taxonomic lists from Lago Maggiore.

The Winter association also contains abundant small single-celled algae, mostly belonging to the X2-Association of Reynolds (1997). They are typical C-strategists, with a high s/v ratio and a high growth rate. Given their active movement capabilities, these algae (Rhodomonas minuta and lacustris, Chrysochromulina parva), are very good competitors under different mixing regimes, but probably do not tolerate a deep mixing and reach their maximum winter development before the onset of the deep overturn.

The Early Spring (ESP) period is largely dominated by the pennate diatoms (Tab. 3). The ESP association is very close to the C-Association by Reynolds (1997), where the large pennates are often co-dominant together with the large centric Stephanodiscus spp., in highly productive lakes: in the southern subalpine lake district, however, the spring development of the large pennates 
(Asterionella formosa, Fragilaria crotonensis and $\mathrm{Au}$ lacoseira sp.) usually characterises the deep oligomesotrophic lakes (Salmaso 2000; Mosello et al. 2001). In these lakes various centric diatoms can be sub-dominant, apparently depending on the trophic status: $C y$ clotella comensis in the oligotrophic Lago Maggiore, Stephanodiscus sp. in the mesotrophic lakes Garda (Salmaso 2000) and Como (Bettinetti et al. 2000).

The long-term changes in the identity of dominant species in the large and deep Lake Constance are in accord with the finding that in large subalpine lakes the pennate diatoms are mostly associated to an oligomesotrophic condition. In fact, Asterionella formosa and Fragilaria crotonensis dominated the spring assemblage in Lake Constance in the pre-eutrophication period, leaving place to Stephanodiscus spp. during the worsening of the lake trophic status and reappearing among the spring dominants during the restoration process (Kümmerlin 1998; Gaedke 1998).

The following seasonal periods (Late Spring and Early Summer) in Lago Maggiore are both characterised by an assemblage with Planktothrix rubescens and Fragilaria crotonensis as the dominant species. The establishment of this new assemblage is possibly linked with the changing physical structure of the water column. The fast and strong decline of the $Z_{m} / Z_{\text {eu }}$ ratio (Figs. 8-9) results in the segregation of a new metalimnetic ecological niche, characterised by low radiation and high nutrient availability. The metalimnetic stratification of Planktothrix rubescens during summer is a well-known phenomenon in lakes (see Reynolds \& Walsby 1975; Klemer 1976; Micheletti et al. 1998). P. rubescens was also found to stratify in the metalimnion of Lake Mergozzo, a small and deep subalpine lake close to Lago Maggiore (Zutshi 1976; Saraceni et al. 1978). This behaviour is due to the species adaptation as a "shade-plant", thanks to its pigment composition and functional morphology, giving this species a high competitive advantage (Reynolds 1997). The elongated shape gives also to Fragilaria crotonensis a high efficiency of light harvesting: this physiological property, together with silicate availability and the thermal gradient slowing down its sedimentation, probably make the metalimnetic layer a favourable environment where Fragilaria can thrive even during summer, although reaching biovolume values usually lower than during Early Spring.

Lindenschmidt \& Chorus (1998) suggest that the summer growth of Fragilaria crotonensis could be explained by an intermittent mixing of the water column: however, in Lago Maggiore this diatom is a typical component of the phytoplanktonic biota during summer, apparently not related to episodes of mixing, as suggested by the lack of relationship between summer wind peaks and Fragilaria growth.

The association Planktothrix rubescens/Fragilaria crotonensis appears therefore favoured by the set of chemical and physical conditions characterising the summer euphotic zone of the deep oligo-mesotrophic lakes, where the metalimnetic layer is sufficiently illuminated (surface shading blooms are extremely rare) and nutrient rich. In fact, this kind of assemblage has been described also in lakes Como (Bettinetti et al. 2000) and Garda (Salmaso 2000): in the latter one it has been recorded at $20 \mathrm{~m}$ depth, thus confirming the adaptation of these two species to the metalimnetic niche.

The importance reached by Mougeotia sp. and $C y$ clotella comensis during summer, could be explained as in Salmaso (2000) for Lago di Garda: both species are good competitors for phosphorus and show low sinking rates.

The Early Spring and Early Summer assemblages include also small flagellated chrysophytes and cryptophytes, able to migrate through the epilimnetic water, exploiting the light in the upper epilimnion and the nutrient availability of the lower epilimnion.

The late summer association is characterised by the decline of Fragilaria crotonensis and the appearance of Ceratium hirundinella: a similar species shift has been also observed in Lake Constance by Sommer (1986), who explained this shift as a consequence of silicate depletion.

Ceratium hirundinella is commonly recorded since Early Spring in significant amount, but only during late Summer it reaches its highest importance: maybe the stability of the water column in late summer represents the ideal environment for the vertical migration of the dinoflagellates searching for nutrients and optimum light intensities.

During August - September Aphanothece sp. was often common in Lago Maggiore, occasionally reaching bloom densities, as recorded during summer 1997. Reynolds (1997) includes these small Chroococcales into the K-Association, typical of small intermittently flushed lakes. In Lago Maggiore, however, the development of these cyanoprokaryota could be mostly related to oligotrophication and to the changes in the phytoplankton community structure (Ruggiu et al. 1998): in fact, they only recently appeared (early 90s; Garibaldi et al. 2000) and their importance progressively increased afterwards. Some recent studies on the picoplankton of Lago Maggiore (Callieri \& Stockner 2000) indicate an increase of picocyanobacteria in the same time period, and suggest that the colonies identified as Aphanothece spp. could be, particularly during late summer, aggregates of picocyanobacteria, more suitable to face unfavourable environmental conditions (Passoni \& Callieri 2000).

Under the attenuated light and temperature of the autumn period a new growth of Planktothrix rubescens, together with a reappearance of Fragilaria crotonensis, probably stimulated by the silicate supply and by an increased $\mathrm{Z}_{\mathrm{m}} / \mathrm{Z}_{\mathrm{eu}}$ ratio, takes place: on the other hand, the presence of Snowella lacustris in the Autumn asso- 
ciation is surprising, as it is usually described as a summer species in the literature (see Reynolds 1997). However, in Lago Maggiore its growth season is often shifted towards the autumn months (Fig. 9). We could hypothesise that some intermittent mixing of the surface water, taking place during the progressive cooling of the epilimnion, could give this species some advantage: it is well known that such a mixing regime can lead, in a suitable environment, to the dominance of Microcystis aeruginosa, a species morphologically and probably also physiologically similar to Snowella lacustris.

In short, the succession pattern described in this chapter and summarised in table 3 can be seen as the main sequence of the phytoplankton succession in Lago Maggiore.

\section{CONCLUSIONS}

In our opinion, the significant result of the present paper is the identification of algal assemblages, typical of each seasonal period in Lago Maggiore. An effort was made to identify both the seasonal periods and the algal assemblages by methods as objective and widely used as possible, though some subjectivity was inevitable in the final step of the assemblages identification, based as they were on a hierarchy of dominant, subdominant and important species.

The identification of a pool of species common to other southern subalpine lakes and the existence of a similar time periodicity in the development and decline of most of them across this lake district would be very promising in order to give our results a wider application. Moreover, as pointed out by other studies (Ruggiu 1983; Salmaso 2000), the physical properties of these lakes, due to their peculiar morphological and hydrological features, probably constitute a sort of standardising factors, forcing the succession pattern towards a limited number of probabilistic outcomes.

Because of this reason, the main sequence of phytoplankton succession recognised during our study could probably fit most of the succession patterns described in the southern deep lakes. However, when applying our model to other deep subalpine lakes, at least three critical points must be emphasised.

The first is that a disturbance can modify the main sequence, determining "shifts" or "reversions" (sensu Reynolds 1980). Examples of this deviations from the main sequence took place during Early Spring and Early Summer 1997 and Autumn 1995, as described in a previous paragraph. In all these events an unusual combination of meteorological parameters probably played a key role in modifying the succession pattern: in Lago Maggiore a strong link between climatic fluctuations and some of the changes recorded in the planktonic events has been often observed during two decades of studies of the phytoplankton evolution (see Morabito 2001 and references therein). Moreover, climatic fluctuations at a larger scale can deeply modify the time course of the phytoplankton succession (Weyhenmeyer et al. 1999; Straile 2000), although no effects on the species composition were recorded until now.

The second point is that our analysis doesn't take into account the structuring role played by the zooplanktonic organisms: even though an evident clearwater phase has been only occasionally observed in Lago Maggiore (i.e. Morabito et al. 1997), anyway it has been demonstrated (Manca \& Ruggiu 1998) that herbivory is an important regulatory factor for the phytoplankton growth in this lake.

Finally, it must be taken into account that most of the deep southern subalpine lakes are still undergoing trophic changes and, therefore, modifications of the phytoplankton assemblages can be expected.

\section{REFERENCES}

Ambrosetti, W., L. Barbanti, R. Mosello \& A. Pugnetti. 1992. Limnological studies on the deep southern Alpine lakes Maggiore, Lugano, Como, Iseo and Garda. Mem. Ist. ital. Idrobiol., 50: 117-146.

Ambrosetti, W. \& L. Barbanti. 1997. Alcune problematiche fisiche dei grandi laghi sudalpini. Documenta Ist. ital. Idrobiol., 61: 3-18.

Ambrosetti, W., L. Barbanti \& A. Rolla. 1997. Meteorologia dell'areale lacustre. In: C.N.R. Istituto Italiano di Idrobiologia, Ricerche sull'evoluzione del Lago Maggiore. Aspetti limnologici. Programma quinquennale 1993-1997. Campagna 1996. Ed. Commissione Internazionale per la protezione delle acque italo-svizzere: 12-17.

Anagnostidis, K. \& J. Komárek. 1988. Modern approach to the classification system of Cyanophytes. 3-Oscillatoriales. Arch. Hydrobiol., Suppl. 80, Algological Studies, 5053: 327-472.

Baldi, E. 1949. La situation actuelle de la recherche limnologique après le Congrès de Zurich. Revue suisse Hydrol., 11: 637-649.

Bettinetti, R., G. Morabito \& A. Provini. 2000. Phytoplankton assemblage structure and dynamics as indicator of the recent trophic and biological evolution of the western basin of Lake Como (N. Italy). Hydrobiologia, 435: 177-190.

Calderoni, A., R. Mosello \& R. de Bernardi. 1997. Le indagini sulla evoluzione dei laghi profondi sudalpini svolte dal C.N.R. Istituto Italiano di Idrobiologia. Documenta Ist. ital. Idrobiol., 61: 19-32.

Callieri, C. \& J. Stockner. 2000. Picocyanobacteria success in oligotrophic lakes: fact or fiction? J. Limnol., 59(1): 7276.

de Bernardi, R., G. Giussani, M. Manca \& D. Ruggiu. 1988. Long-term dynamics of plankton communities in Lago Maggiore (N. Italy). Verh. int. Ver. Limnol., 23: 729-733.

Gaedke, U. 1998. Functional and taxonomical properties of the phytoplankton community of large and deep Lake Constance: Interannual variability and response to re-oligotrophication (1979-1993). Arch. Hydrobiol., Spec. Issues Advanc. Limnol., 53: 119-141.

Garibaldi, L., F. Buzzi, G. Morabito, N. Salmaso \& M. Simona. 2000. I cianobatteri fitoplanctonici dei laghi profondi dell'Italia Settentrionale. Rapporti ISTISAN, 00/30: 117-135.

Guilizzoni, P., G. Bonomi, G. Galanti \& D. Ruggiu. 1983. Relationship between sedimentary pigments and primary production: evidence from core analyses of twelve Italian lakes. Hydrobiologia , 103: 103-106.

Harris, G.P. 1980. Temporal and spatial scales in phytoplankton ecology. Mechanisms, methods, models and management. Can. J. Fish. Aquat. Sci., 37: 877-900. 
Harris, G.P. 1994. Pattern, process and prediction in aquatic ecology. A limnological view of some general ecological problems. Freshwat. Biol., 32: 143-160.

Hutchinson, G.E. 1957. A Treatise on Limnology. Vol. I. Geography, physics and chemistry. Wiley \& Sons, London: $1015 \mathrm{pp}$

Kirk, J.T.O. 1994. Light and photosynthesis in aquatic ecosystems. Cambridge University Press (Second Edition): $509 \mathrm{pp}$.

Klemer, A.R. 1976. The vertical distribution of Oscillatoria agardhii var. isothrix. Arch. Hydrobiol., 78: 343-362.

Kümmerlin, R.E. 1998. Taxonomical response of the phytoplankton community of Upper Lake Constance (BodenseeObersee) to eutrophication and re-oligotrophication. Arch. Hydrobiol., Spec. Issues Advanc. Limnol., 53: 109-117.

Libera, V. \& A. Carollo. 1997. Indagini sul bacino imbrifero. Caratteristiche idrologiche. In: C.N.R. Istituto Italiano di Idrobiologia, Ricerche sull'evoluzione del Lago Maggiore. Aspetti limnologici. Programma quinquennale 1993-1997. Campagna 1996. Ed. Commissione Internazionale per la protezione delle acque italo-svizzere: 5-11.

Lindenschmidt, K.E. \& I. Chorus. 1998. The effect of water column mixing on phytoplankton succession, diversity and similarity. J. Plank. Res., 20(10): 1927-1951.

Lund, J.W.G., C. Kipling \& E.D. Le Cren. 1958. The inverted microscope method of estimating algal numbers and the statistical basis of estimations by counting. Hydrobiologia, 11: $143-170$

Manca, M. \& D. Ruggiu. 1998. Consequences of pelagic foodweb changes during a long-term lake oligotrophication process. Limnol. Oceanogr., 43(6): 1368-1373.

Manca, M., A. Calderoni \& R. Mosello. 1992. Limnological research in Lago Maggiore: studies on hydrochemistry and plankton. Mem. Ist. ital. Idrobiol., 50: 171-200.

Manca, M., M. Beltrami \& A. Carnovale. 1998. Popolamenti planctonici. Indagini sullo zooplancton. In: C.N.R. Istituto Italiano di Idrobiologia, Ricerche sull'evoluzione del Lago Maggiore. Aspetti limnologici. Programma quinquennale 1998-2002. Campagna 1998. Ed. Commissione Internazionale per la protezione delle acque italo-svizzere: 5053.

Manca, M., N. Cavicchioni \& G. Morabito. 2000. First observations on the effect of a complete, exceptional overturn of Lake Maggiore on plankton and primary production. Internat. Rev. Hydrobiol., 85(2-3): 209-222.

Marchetto, A., A. Lami, S. Musazzi, L. Guzzella, L. Langone, J. Massaferro, R. Bettinetti, G. Morabito \& P. Guilizzoni. 2000. Reconstruction of the recent eutrophication and oligotrophication history of a large sub-alpine lake (Lake Maggiore, $N$. Italy). 8th International Symposium on $\mathrm{Pa}-$ leolimnology. Kingston, Ontario, Canada (poster)

Micheletti, S., F. Schanz \& A.E. Walsby. 1998. The daily integral of photosynthesis by Planktothix rubescens during summer stratification and autumnal mixing in Lake Zürich. New Phytol., 139: 233-246.

Monti, R. 1929. Limnologia comparata dei laghi insubrici. Verh. int. Ver. Limnol., 4: 462-497.

Morabito, G. 2001. Relationships between phytoplankton dynamics in Lake Maggiore and local climate in the period 1978-'98. Atti dell'Associazione Italiana di Oceanologia e Limnologia, 14: 147-156.

Morabito, G. \& A. Pugnetti. 2000. Primary productivity and related variables in the course of the trophic evolution of Lake Maggiore. Verh. int. Ver. Limnol., 27: 2934-2937.

Morabito, G., M. Manca \& D. Ruggiu. 1997. Seasonal dynamics of planktonic communities in Lago Maggiore and clear-water phase during 1993. Atti del $12^{\circ}$ Congresso dell'Associazione Italiana di Oceanologia e Limnologia: 265-274.
Mosello, R. \& D. Ruggiu. 1985. Nutrient load, trophic conditions and restoration prospects of Lake Maggiore. Int. Revue ges. Hydrobiol., 70: 63-75.

Mosello, R., M.C. Brizzio, F. Buzzi, L. Colzani, E. Pizzotti \& D. Mocellin. 2001. Qualità delle acque dei tributari e del Lario nel biennio 1998-1999. Atti dell'Associazione Italiana di Oceanologia e Limnologia, 14: 137-146.

Padisák, J. 1992. Seasonal succession of phytoplankton in a large shallow lake (Balaton, Hungary) - a dynamic approach to ecological memory, its possible role and mechanisms. J. Ecol., 80: 217-230.

Padisák, J. \& M. Dokulil. 1994. Meroplankton dynamics in a saline, turbid, shallow lake (Neusiedlersee Austria/Hungary). Hydrobiologia, 289: 23-42.

Passoni, S. \& C. Callieri. 2000. Picocyanobacteria single forms, aggregates and microcolonies: survival strategy or special succession? Verh. int. Ver. Limnol., 27: 18791883.

Ravera, O. \& R.A. Vollenweider. 1968. Oscillatoria rubescens D.C. as an indicator of Lago Maggiore eutrophication. Schweiz Z. Hydrol., 30: 374-380.

Reynolds, C.S. 1980. Phytoplankton assemblages and their periodicity in stratifying lake systems. Holarctic Ecol., 3: 141-159.

Reynolds, C.S. 1984. Phytoplankton periodicity: the interactions of form, function and environmental variability. Freshwat. Biol., 14: 111-142.

Reynolds, C.S. 1997. Vegetation processes in the pelagic: a model for ecosystem theory. Ecology Institute, Oldendorf/Luhe, Germany: $371 \mathrm{pp}$.

Reynolds, C.S. 1998. What factors influence the species composition of phytoplankton in lakes of different trophic status? Hydrobiologia, 369/370 (Dev. Hydrobiol., 129): 11-26.

Reynolds, C.S. 1999. Metabolic sensitivities of lacustrine ecosystems to anthropogenic forcing. Aquat. Sci., 61: 183205.

Reynolds, C.S. \& A.E. Walsby. 1975. Water blooms. Biol. Rev., 50: 437-481.

Ruggiu, D. 1983. Caratteristiche e comportamento del fitoplancton nei laghi profondi sudalpini. In: W. Ambrosetti, L. Barbanti, R. Mosello, A. Rolla \& D. Ruggiu, Mescolamento, caratteristiche chimiche, fitoplancton e situazione trofica nei laghi profondi sudalpini. C.N.R. AQ/2/20: 105145.

Ruggiu, D. 1993. Osservazioni conclusive. Considerazioni generali sull'evoluzione a lungo termine dei popolamenti planctonici. Fitoplancton. In: C.N.R. Istituto Italiano di Idrobiologia, Ricerche sull'evoluzione del Lago Maggiore. Aspetti limnologici. Campagna 1992 e Rapporto quinquennale 1988-1992. Ed. Commissione Internazionale per la protezione delle acque italo-svizzere: 115-116.

Ruggiu, D. \& C. Saraceni. 1977. Fitoplancton, clorofilla e produzione primaria nel Lago Maggiore durante gli anni 1972-1973. Mem. Ist. ital. Idrobiol., 34: 57-78.

Ruggiu, D., G. Morabito, P. Panzani \& A. Pugnetti. 1998. Trends and relations among basic phytoplankton characteristics in the course of the long-term oligotrophication of Lake Maggiore. Hydrobiologia, 369/370: 243-257.

Salmaso, N. 1996. Seasonal variation in the composition and rate of change of the phytoplankton community in a deep subalpine lake (Lake Garda, Northern Italy). An application of nonmetric multidimensional scaling and cluster analysis. Hydrobiologia, 337: 49-68.

Salmaso, N. 2000. Factors affecting the seasonality and distribution of cyanobacteria and chlorophytes: a case study from the large lakes south of the Alps, with special reference to Lake Garda. Hydrobiologia, 438: 43-63.

Saraceni, C., D. Ruggiu \& M. Nakanishi. 1978. Phytoplankton dynamics, chlorophyll $a$ and phaeophytin in Lago di Mer- 
gozzo (Northern Italy). Mem. Ist. ital. Idrobiol., 36: 215237.

Seip, K.L. \& C.S. Reynolds. 1995. Phytoplankton functional attributes along trophic gradient and season. Limnol. Oceanogr., 40(3): 589-597.

Skulberg, O.M. \& R. Skulberg. 1985. Planktic species of Oscillatoria (Cyanophyceae) from Norway. Arch. Hydrobiol., Suppl. 71(1/2): 157-174.

Smayda, T.J. 1978. From phytoplankters to biomass. In: A. Sournia (Ed.), Phytoplankton Manual. UNESCO, 23: 273 279 .

Sommer, U. 1986. The periodicity of phytoplankton in Lake Constance (Bodensee) in comparison to other deep lakes of central Europe. Hydrobiologia, 138: 1-7.

StatSoft Inc. 1997. Statistica for Windows (Computer programm manual). StatSoft, Inc., Tulsa, OK: 958 pp.
Straile, D. 2000. Meteorological forcing of plankton dynamics in a large and deep continental European lake. Oecologia, 122: 44-50.

Vollenweider, R.A. 1965. Materiali ed idee per una idrochimica delle acque insubriche. Mem. Ist. ital. Idrobiol., 19: 213-286.

Walsby, A.E., A. Avery \& F. Schanz. 1998. The critical pressures of gas vesicles in Planktothrix rubescens in relation to the depth of winter mixing in Lake Zurich, Switzerland. J. Plankton Res., 20: 1357-1375.

Weyhenmeyer, G.A., T. Blenckner \& K. Pettersson. 1999. Changes of the plankton spring outburst related to the North Atlantic Oscillation. Limnol. Oceanogr., 44(7): 1788-1792.

Zutshi, D.P. 1976. Phytoplankton productivity, algal dynamics and trophic status of Lake Mergozzo (Northern Italy). Mem. Ist. ital. Idrobiol., 33: 221-256. 